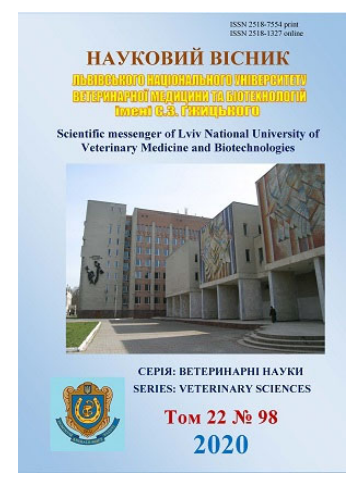

Науковий вісник Яьвівського національного університету ветеринарної медицини та біотехнологій імені С.3. Гжицького. Серія: Ветеринарні науки

\author{
Scientific Messenger of Lviv National University \\ of Veterinary Medicine and Biotechnologies. \\ Series: Veterinary sciences
}

doi: $10.32718 /$ nvlvet9814

https://nvlvet.com.ua/index.php/journal

UDC 637.5'65:637.04:579

\title{
Determination of bacitracin groups residue in poultry products by microbiological method
}

\author{
I. M. Azyrkina, T. A. Garkavenko, T. G. Kozytska, L. O. Shalimova
}

State Research Institute for Laboratory Diagnostics and Veterinary and Sanitary Expertise, Kyiv, Ukraine

Article info

Received 27.03.2020

Received in revised form 04.05 .2020

Accepted 05.05.2020

State Research Institute for Laboratory Diagnostics and Veterinary and Sanitary

Expertise, Donetska Str., 30, Kyiv, 02000, Ukraine.

Tel.: +38-097-972-49-63

E-mail:microb_antib@ukr.net
Azyrkina, I. M., Garkavenko, T. A., Kozytska, T. G., \& Shalimova, L. O. (2020). Determination of bacitracin groups residue in poultry products by microbiological method. Scientific Messenger of Lviv National University of Veterinary Medicine and Biotechnologies. Series: Veterinary sciences, 22(98), 79-83. doi: $10.32718 /$ nvlvet9814

\begin{abstract}
Antibiotics are widely used to stimulate the growth of poultry raised for human consumption, as well as therapeutically for the treatment of infectious diseases of poultry. The indiscriminate use of antibiotic growth stimulants in chicken diets continues to pose a threat to human health. However, because the burden of infectious diseases in poultry is high, the abolition of the use of antibiotics without alternatives will lead to the spread of infections that have serious consequences for food safety and human health. One of the priorities of the state policy on nutrition in the field of health care is to ensure food safety. The aim of the study was to determine the residual amount of antibiotics in poultry meat, liver and kidneys. To validate a qualitatively new screening microbiological method to determine the residual amount of the bacitracin group in poultry products. Material and methods. The limits of sensitivity, accuracy and specificity were established by microbiological method for determining the residual amount of the bacitracin group. The study was performed in 20 replicates of meat, liver and kidney samples that do not contain antibiotics, as well as in samples with the addition of antibiotics of the bacitracin group in concentrations $1 / 2$ MRL and MRL. Results of research and discussion. Pure inhibition zones with growth of Micrococcus flavus ATCC 10240 test culture were found in the samples without the addition of antibiotics, and inhibition zones ranging from $18.03 \pm 0.03 \mathrm{~mm}$ to $18.08 \pm 0.04 \mathrm{~mm}$ were present near the standard of antibiotics. It was found that when adding an antibiotic of the bacitracin group to poultry products, were present around the wells of the inhibition zone of the test culture Micrococcus flavus ATCC 10240. The lowest level of residue determination (1/2MRL) for poultry, kidney and liver is $10.0 \mu \mathrm{g} / \mathrm{kg}, M R L 20.0 \mu \mathrm{g} / \mathrm{kg}$ in accordance with the requirements of national legislation by order of the Ministry of Health of Ukraine Poultry meat safety parameters from 06.08.2013 № 695. Conclusions and prospects for further research. The specificity, accuracy and sensitivity of this method is $100 \%$, which allows to detect $1 / 2$ maximum permissible levels of residual amounts of antibiotics of the bacitracin group in accordance with the requirements of national legislation.
\end{abstract}

Key words: test culture, Micrococcus flavus ATCC 10240, residual amounts of antibiotics, bacitracin, meat, liver, kidneys.

\section{Визначення залишкових кількостей антибіотиків групи бацитрацинів у продукції птахівництва мікробіологічним методом}

\author{
I. М. Азиркіна, Т. О. Гаркавенко, Т. Г. Козицька, Л. О. Шалімова
}

Державний науково-дослідний інститут з лабораторної діагностики та ветеринарно-санітарної експертизи, м. Київ, Україна

Антибіотики широко використовуються для стимулювання росту птиці, яку вирощують для використання в їжу, а також терапевтично для лікування інфекційних захворювань птиці. Нерозбірливе використання стимуляторів росту антибіотиків у курячих дієтах продовжує становити загрозу здоров'ю людини. Однак, оскільки навантаження на інфекційні захворювання в 
птахогосподарствах велике, скасування використання антибіотиків без альтернатив призведе до поширення інфекиій, щзо мають серйозні наслідки для безпеки продуктів харчування та здоров'я людини. Одним із пріоритетних напрямків державної політики шодо харчування в галузі охорони здоров'я є забезпечення безпеки харчових продуктів. Метою роботи було провести дослідження щзодо визначення залишкової кількості антибіотиків у м'ясі, печінці та нирках птиці. Провести валідацію якісного нового скринінгового мікробіологічного методу визначення залишкової кількості групи бацитрацинів в продукції птахівництва. Матеріал та методи. Межі чутливості, точності та специфічності були встановлені мікробіологічним методом визначення залишкової кількості групи бацитрацинів. Дослідження проводилось у 20 повторюваностях зразків м'яса, печінки та нирок, які не містять антибіотики, а також у зразках із додаванням антибіотиків групи бацитрацинів у концентраціях 1/2 МДР та МДР. Результати дослідження та обговорення. Виявили в зразках без додавання антибіотиків чисті зони інгібування з ростом тест-культури Містососcus flavus ATCC 10240, а біля стандарту антибіотиків присутні зони інгібування, які становили від 18,03 \pm 0,03 мм до 18,08 \pm 0,04 мм. Встановлено, щзо при додаванні антибіотика групи бацитрацинів у м'ясо, печінку, нирки про щзо свідчить присутність навколо луночок зони інгібування тест-культури Місrососси flavus ATCC 10240 в тестовому агарі. Найнижчий рівень визначення залишків 10,0 мкг/кг (1/2 МДР) для м'яса птичі, нирок та печінки становить, МДР 20,0 мкг/кг відповідно до вимог національного законодавства від 06.08.2013 року № 695 наказ Міністерства охорони здоров'я Украӥни “Параметрів безпечності м'яса птиці”, Висновки та перспективи подальших досліджень. Визначено специфічність, точність та чутливість изього методу становить $100 \%$ шео дозволяє виявляти 10 мкг/кг (1/2 максимально допустимих рівнів) залишкових кількостей антибіотиків групи бацитрацинів відповідно до вимог національного законодавства.

Ключові слова: залишкові кількості антибіотиків, бацитраџин, тест-культура Micrococcus flavus ATCC 10240, м'ясо, печінка, нирки, птиия.

\section{Вступ}

Антибіотики групи бацитрацину - це суміш різноманітних поліпептидів, серед яких найбільшою активністю володіє бацитрацин А (діюча речовина “бациліхін”, “цикатрин”, “полібактрин”). Формула бацитрацину $\mathrm{C}_{66} \mathrm{H}_{103} \mathrm{~N}_{17} \mathrm{O}_{16} \mathrm{~S}$. Бацитрацин виділено в 1945 р., продуцентом цього антибіотика є Bacillus licheniformis, відомий як кормова добавка Е 700.

Крім використання з лікувальною метою у ветеринарії, бацитрацин застосовують профілактично, оскільки він $є$ стимулятором росту при вирощуванні птиці. Антибіотики широкого спектру дії володіють бактерицидними властивостями щодо грампозитивних та грамнегативних бактерій (пневмокок, стрептокок, стафілокок і клостридії) завдяки здатності інгібувати синтез клітинної стінки (Smith \& Weinberg, 1962; Stutz et al., 1983; Frost \& Woolcock, 1991; Biyashev et al., 2009; Sosina et al., 2012).

Bacillus licheniformis виробляють різноманітні токсини системної дії, викликають запалення слизової оболонки кишечнику, що перешкоджає всмоктуванню поживних речовин з просвіту кишечнику. Бацитрацин гальмує ріст і розвиток хвороботворних організмів, запобігає токсикогенезу, не пригнічуючи мікроорганізми, які стимулюють процеси травлення. Застосування бацитрацину не призводить до збільшення кількості мікробів, стійких до тетрацикліну та інших антибіотиків. Бациліхін (діюча речовина бацитрацин) випускається двох видів: Бациліхін-90 і Бациліхін-120 (Engberg et al., 2000).

Проте бацитрацин є одним із найтоксичніших серед інших антибіотиків, володіє нефротоксичною дією, часто викликає алергії, при внутрішньом'язовому введенні може викликати некроз тканин. У зв'язку з цим на даний час для лікування людей бацитрацин застосовують виключно зовнішньо у складі мазей (Prescott et al., 1978; Shershnev et al., 1998).

Залишкові кількості препарату можуть залишатись у продукції птахівництва і спричиняти шкоду здоров'ю споживача. Контроль залишків групи бацитрацинів у продукції птахівництва в Україні регламен- туються Наказом Міністерства охорони здоров'я України про затвердження Параметрів безпечності м'яса птиці від 06.08.2013 року № 695. На даний час українські лабораторії в своїй роботі використовують для визначення залишкових кількостей цинкбацитрацину "Методичні вказівки по визначенню залишкових кількостей антибіотиків у продуктах тваринництва за № 3049-84 від 1984 р." цей метод є трудомісткий, складний, займає багато часу на готування проб та проведення дослідження. Тому нами було розроблено новий скринінговий мікробіологічний метод щодо визначення залишкових кількостей групи бацитрацинів на основі методу NAT-screening (Nachkebia et al., 2006; Nurlanova, 2007; Melihov \& Radionov, 2012; Gondova \& Kožárová, 2012; Campbell-Platt, 2019).

В основі мікробіологічного методу визначення залишкових кількостей групи бацитрацинів лежить принцип дифузії в агар, тобто здатність антибіотиків дифундувати в щільне поживне середовище, інокульоване специфічним чутливим тестмікроорганізмом. Наявність залишкових кількостей групи бацитрацинів у пробі визначається появою в агарі чітко окреслених, чистих від росту тесткультури мікроорганізмів зон (Melihov \& Radionov, 2012; Campbell-Platt, 2019).

Мета роботи полягала в проведенні апробації, валідації якісного скринінг-мікробіологічного методу щодо визначення залишкових кількостей антибіотиків групи бацитрацинів у продукції птахівництва.

Для досягнення даної мети поставлені такі завдання:

- дослідити у 20 повторюваностях м'ясо, нирки та печінку птиці без додавання аналітумікробіологічним методом;

- визначити залишкову кількість бацитрацину в 20 повторюваностях м'яса, нирок та печінки птиці додаванням аналіту на рівні $1 / 2$ МДР та МДР (максимально допустимий рівень); дослідити на спецефічність у 20 повторюваностях м'ясо, нирки та печінку птиці 3 додаванням інших груп антимікробних препаратів. 


\section{Матеріал і методи досліджень}

Для встановлення межі чутливості мікробіологічного методу з визначення залишків антибіотиків групи бацитрацинів було проведено дослідження на модельованих пробах м'яса курячого, качиного, індичого, печінки та нирок, вільних від антибіотиків (негатив), та в пробах із внесеними стандартними розчинами бацитрацину в концентраціях $1 / 2$ МДР $(10 \pm 1$ мкг/кг) і МДР $(20 \pm 1$ мкг/кг). Дослідження проводились у 20 повторюваностях кожної матриці. Проби добре гомогенізували, зважили, додали аналіт, гомогенізували протягом 1 години. Помістили в холодильник на 12 год за температури від $0{ }^{\circ} \mathrm{C}$ до $+4{ }^{\circ} \mathrm{C}$. Потім готували проби до відповідних стандартних операційних процедур (Commission Decision, 2002, Commission Regulation, 2010; Coppens, 2012).

Cnецефічість. Характеризує здатність методу недвозначно визначити компонент у присутності інших компонентів. Збагатили проби на рівні Цільової концентрації скринінгу й Регулятивною межею. Чим нижча Цільова концентрація скринінгу в порівнянні 3 Регулятивною межею, тим менше реплікатів потрібно проаналізувати. Для випробування беруть стільки проб, скільки потрібно для того щоб, вистачило б дослідити 20 проб негативного контролю та по 20 проб з добавкою аналіту на різних рівнях концентрації та встановити:

- чи дійсно дана речовина інтерферує з аналітом;

- чи заважає присутність даної домішки визначати аналіт;

- чи впливає домішка на кількісне визначення аналіту.

Для визначення специфічності до аналогічних матриць було внесено антимікробні препарати у концентрації: окситетрацикліну - 100 мкг/кг, тилозину 100 мкг/кг, дигідрострептоміцину - 500 мкг/кг, флюмеквіну - 400 мкг/кг.

Підготовка тест-культури Micrococcus flavus АТСС 10240 та чашок Петрі з тестовим агаром. Для дослідження використовували музейний штам тесткультури Micrococcus flavus ATCC 10240, чутливої до групи бацитрацинів, суспензію у концентрації $10^{6} \mathrm{KУO} / \mathrm{cm}^{3}$ внесли 200 мкл в поживне середовище Iso-sensitest agar (HIMEDIA, Індія) $3 \mathrm{pH}$ 7,0. на $100 \mathrm{~cm}^{3}$. Поживне середовище заливали в чашки Петрі шаром 2,5 мм.

Стандарт антибіотика. Використовували стандарт “Цинкбацитрацин” (Sigma Aldrich, США). Основний розчин антибіотика розводили дистильованою водою. Розчин цинкбацитрацин 3 активністю

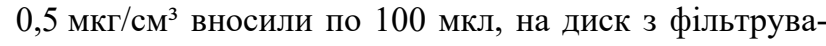
льного паперу діаметром 12,7 мм (Whatman, Schleicher\&Schuell, Hertogenbosch, Нідерланди) в чашки з тестовим агаром.

Підготовка проб до дослідження. Проби продукції птахівництва виймали з морозильної камери за кілька хвилин перед дослідженням, поверхню м'яса, печінки, нирок вирівнювали і робили поперечні надрізи скальпелем в які вкладали диски 3 фільтрувального паперу діаметром 12,7 мм на 30 хв з метою просочування м'ясною рідиною.

В кожній чашці з тестовим агаром робили по 3 лунки діаметром 14 мм, в які заливали 1,5 М фосфатний буферний розчин $(\mathrm{pH} 7,0)$ до межі луночки, після чого в дві луночки вкладали диски, просочені рідиною однієї проби, один навпроти одного, а в третю луночку диск із стандартом цинкбацитрацину.

Чашки інкубували протягом 16-18 годин за температури $37 \pm 1{ }^{\circ} \mathrm{C}$. Після інкубації чашки оглядали на наявність навколо лунок зон інгібування росту тесткультури Micrococcus flavus ATCC 10240. Наявність зон розміром більше ніж 15 мм вказувала на присутність залишків групи бацитрацинів у пробах. Вимірювання діаметру зон інгібування проводили лінійкою.

Отримані результати обробляли методами варіаційної статистики 3 використанням програми "Microsoft Excel 2015" з обчисленням середнього арифметичного (M), стандартної похибки (m) та рівня вірогідності (Р) за таблицею Стьюдента. Різницю між двома величинами вважали вірогідною при $\mathrm{P} \leq 0,05$; $\mathrm{P} \leq 0,01 ; \mathrm{P} \leq 0,001$.

Також визначали точність, специфічність, чутливість методу згідно з ДСТУ ISO 16140:2006 (DSTU ISO 16140:2006).

\section{Результати та їх обговорення}

За результатами досліджень встановлено, що чутливість методу для групи бацитрацинів відповідає максимально допустимим рівням (МДР), що визначені в наказі Міністерства охорони здоров'я України "Параметрів безпечності м'яса птиці" від 06.08.2013 року № 695 для продукції птахівництва.

Так, в ході проведених досліджень встановлено, що навколо луночок із внесеним стандартом цинкбацитрацину спостерігаються чітко окреслені, чисті від росту тест-культури Micrococcus flavus ATCC 10240 зони інгібування які коливаються в межах від $18,03 \pm 0,03$ мм до 18,08 \pm 0,04 мм.

У пробах продукції птахівництва, в які було внесено бацитрацин, навколо дисків, просочених рідиною проби, спостерігали чітко окреслені зони затримки росту тест-культури Micrococcus flavus ATCC 10240. Результати щодо діаметрів зон інгібування для різних видів проб наведені в табл. 1-3.

Аналізуючи одержані результати, за умови додаванням бацитрацину на рівні $1 / 2$ МДР спостерігали, що навколо проб м'яса зони інгібування в середньому $18,09 \pm 0,05$ мм.

Що ж до результатів із додавання бацитрацину на рівні 1 МДР проб м'яса зони інгібування зростали в середньому до 19,07 \pm 0,04 мм. (табл. 1).

В пробах печінки з додаванням бацитрацину на рівні 1/2 МДР зони затримки росту становили навколо проб в середньому 19,05 \pm 0,03 мм, відповідно на рівні 1 МДР зони затримки росту були більшими та становили всередньому до 21,04 $\pm 0,03$ мм навколо дисків, просочених пробою печінки (табл. 2). 
В пробах нирок найнижчі зони затримки росту спостерігали навколо проб із додаванням бацитрацину на рівні 1/2 МДР та становили в середньому
$19,03 \pm 0,05$ мм, для проб цей показник був дещо вищим на рівні 1 МДР і становив і становив в середньому 20,07 $\pm 0,04$ мм (табл. 3).

\section{Таблиця 1}

Діаметри зон затримки росту тест-культури Micrococcus flavus ATCC 10240 навколо проб м'яса 3 додаванням бацитрацину, $\mathrm{M} \pm \mathrm{m}, \mathrm{Mм}, \mathrm{n}=20$

\begin{tabular}{cccc}
\hline \multirow{2}{*}{ М'ясо } & \multicolumn{2}{c}{ Концентрація бацитрацину в пробах } \\
\cline { 2 - 4 } & Негативний контроль & $\begin{array}{c}\text { Контроль } \\
\text { (стандарт) }\end{array}$ & $\begin{array}{c}\text { Проба з додаванням } \\
\text { аналіту на рівні 1/2 МДР }\end{array}$ \\
\hline Куряче & Відсутні зони затримки росту & $18,03 \pm 0,05^{*}$ & $18,075 \pm 0,04^{*}$ \\
Качине & тест-культури навколо дисків, & $18,05 \pm 0,03^{*}$ & $18,1 \pm 0,05^{*}$ \\
Індиче & просочених рідиною проби & $18,08 \pm 0,04^{*}$ & $18,1 \pm 0,05^{*}$ \\
Примітка $: * \mathrm{P} \leq 0,05 ;$ різниця значень показника концентрацій антимікробних препаратів щодо негативного контролю
\end{tabular}

\section{Таблиця 2}

Діаметри зон затримки росту тест-культури Micrococcus flavus ATCC 10240 навколо проб печінки 3 додаванням бацитрацину, $\mathrm{M} \pm \mathrm{m}, \mathrm{MM}, \mathrm{n}=20$

\begin{tabular}{llccc}
\hline \multirow{2}{*}{ Печінка } & \multicolumn{4}{c}{ Концентрація бацитрацину в пробах } \\
\cline { 2 - 5 } & \multicolumn{1}{c}{ Негативний контроль } & $\begin{array}{c}\text { Контроль } \\
\text { Кстандарт) }\end{array}$ & $\begin{array}{c}\text { Проба 3 додаванням } \\
\text { аналіту на рівні 1/2 МДР }\end{array}$ & $\begin{array}{c}\text { Проба 3 додаванням } \\
\text { аналіту на рівні 1 МДР }\end{array}$ \\
\cline { 2 - 5 } Качине & Відсутні зони затримки росту & $18,05 \pm 0,03 *$ & $19,05 \pm 0,03 *$ & $21,03 \pm 0,03 *$ \\
Індиче & тест-культури навколо дисків, & $18,03 \pm 0,03 *$ & $19,03 \pm 0,03 *$ & $21,05 \pm 0,03 *$ \\
\hline
\end{tabular}

Примітка: * $\mathrm{P} \leq 0,05$; різниця значень показника концентрацій антимікробного препарату щодо негативного контролю

\section{Таблиця 3}

Діаметри зон затримки росту тест-культури Micrococcus flavus ATCC 10240 навколо проб нирок 3 додаванням бацитрацину, $\mathrm{M} \pm \mathrm{m}, \mathrm{Mм}, \mathrm{n}=20$

\begin{tabular}{|l|c|c|c|c|}
\hline \multirow{2}{*}{ Нирки } & \multicolumn{4}{|c|}{ Концентрація бацитрацину в пробах } \\
\cline { 5 - 6 } & Негативний контроль & $\begin{array}{c}\text { Контроль } \\
\text { (стандарт) }\end{array}$ & $\begin{array}{c}\text { Проба з додаванням } \\
\text { аналіту на рівні 1/2 МДР }\end{array}$ & $\begin{array}{c}\text { Проба з додаванням аналі- } \\
\text { ту на рівні } 1 \mathrm{MДР}\end{array}$ \\
\hline Куряче & Відсутні зони затримки росту & $18,03 \pm 0,03^{*}$ & $19,08 \pm 0,04^{*}$ & $20,050 \pm 0,03^{*}$ \\
\cline { 1 - 1 } Качине & тест-культури навколо дисків, & $18,05 \pm 0,03^{*}$ & $19,01 \pm 0,05^{*}$ & $20,075 \pm 0,04^{*}$ \\
\cline { 3 - 5 } Індиче & просочених рідиною проби & $18,05 \pm 0,03^{*}$ & $19,01 \pm 0,05^{*}$ & $20,075 \pm 0,04^{*}$ \\
\hline
\end{tabular}

Примітка: * $\mathrm{P} \leq 0,05$; різниця значень показника концентрацій антибіотика щодо негативного контролю

Виходячи $з$ отриманих результатів, можна дійти висновку, що найнижчий рівень визначення (1/2 МДР) залишкових кількостей антибіотиків групи бацитрацинів для Micrococcus flavus ATCC 10240, тобто чутливість методу для м'яса птиці, нирок, печінки становить 10,0 мкг/кг бацитрацину.

Cпециффічність. Характеризується відсутністю помилкових (помилково позитивних) результатів, тобто ймовірністю одержати негативний результат у проб 3 додаванням різних антибіотиків у пробу. Специфічність якісного методу є якісне поняття - це ступінь того, як компоненти, відмінні від цільового аналіту, впливають на результати аналізування. Цю надзвичайно важливу рису методу також можна визначити як здатність забезпечувати результати, на які не впливає матриця. Чим вище селективність, тим більша є достовірність ідентифікації та класифікації проби.

Щодо проб із вмістом окситетрацикліну, тилозину, дигідрострептоміцину, флюмеквіну і сульфадіазину зони інгібування навколо луночок із внесеними антимікробними препаратами були відсутні.
Tочність. Характеризується ступеню близькості результатів для серії вимірювань, виконаних на різних пробах однієї й тієї ж однорідної проби.

При виконанні дослідження спостерігали $100 \%$ узгодженість між результатами досліджень та пробами 3 різними способами та рівнями контамінації.

\section{Висновки}

1. Встановлено, що чутливість скринінгового мікробіологічного методу 3 визначення залишкових кількостей групи бацитрацинів у м'ясі птиці, печінці, нирках мікробіологічним методом 10 мкг/кг (1/2 МДР), що відповідає вимогам, які встановлені наказом Міністерства охорони здоров'я України про затвердження Параметрів безпечності м'яса птиці від 06.08.2013 року № 695. Відповідно найнижчий рівень визначення 1/2 МДР становить 10,0 мкг/кг бацитрацину.

2. Встановлено, що специфічність та точність визначення залишкових кількостей антибіотиків групи 
бацитрацинів у м’ясі, печінці, нирках мікробіологічним методом становить $100 \%$.

Перспективи подальших досліджень. У зв'язку з розширенням критеріїв дослідження м'яса птиці, печінки, нирок на залишкові кількості антибіотиків у рамках періодичного контролю даний метод рекомендовано впровадити в роботу лабораторій Держпродспоживслужби.

\section{References}

Biyashev, K. B., Sanserbaeva, N. B., \& Mustafina, Sh. A. (2009). Eksperementalnyie dannyie o soderzhanii antibiotikov v organah i tkanyah [Experimental data on the content of antibiotics in tissues and organs]. Veterinariya - Veterinary Sciences, 5, 103-106 (in Russian).

Campbell-Platt, G. (2019). A new microbial screening method for the detection of antimicrobial residues in slaughter animals: The Nouwsantibiotictest (NAT screening). Retrieved from http://www.elsevier.com/ locate/foodcont.

Commission Decision 2002/657/EC of 12 August 2002 implementing Council Directive 96/23/EC concerningthe performance of analytical methods and the interpretation of results. Official Journal of the European Commission, L. 221, 8-28.

Commission Regulation (EU) № 37/2010. (2010). Official journal of the Europen Commission, 15, 72.

Coppens, Nico (2012). Microbial screening tests for antibiotic residues in meat: compared with the European technologies - Ghent university veterinary faculty. Retrieved from: https://lib.ugent.be/fulltxt/RUG01/ 001/893/681/RUG01-001893681_2012_0001_AC.pdf.

DSTU ISO 16140:2006 Mikrobiologiya xarchovyx produktiv ta kormiv dlya tvaryn. Protokol validaciyi alternatyvnyx metodiv (ISO 16140:2003, IDT) (in Ukrainian).

Engberg, R. M., Hedemann, M. S., Leser, T. D., \& Jensen, B. B. (2000). Effect of zinc bacitracin and salinomycin on intestinal microflora and performance of broilers. Poultry Science, 79(9), 1311-1319. doi: $10.1093 / \mathrm{ps} / 79.9 .1311$.

Frost, A. J., \& Woolcock, J. B. (1991). Antibiotics and animal production. In: Woolcock J.B, editor. Microbiology of Animals and Animal Products. New York, NY: Elsevier, 181-194. https://agris.fao.org/agrissearch/search.do?recordID=NL9203968.
Gondova, Z., \& Kožárová, I. (2012). The NAT test screening for antibiotic residues in the tissues of foodproducing animals. Maso international, 2, 95-100. Retrieved from: http://www.maso-international.cz/ download/maso-international-2012-2-page-095100.pdf

Melihov, S. V., \& Radionov, V. N. (2012). Primenenie kompleksnyih antibakterialnyih preparatov $\mathrm{V}$ ptitsevodstve i zhivotnovodstve [The use of complex antibacterial drugs in poultry and livestock]. Veterinariya Kubani - Kuban Veterinary, 6, 6-8 (in Russian).

Nachkebia, J. V., Nachkebia, E. J., \& Nachkebia, K. J. (2006). Casual Conditionality of Pathogen Features of Escherichia due to their Joint Inhabitance with Oxygenic Clostridia. Annals of Agrarian Science, 3(4), 195-197.

Nurlanova, A. A. (2007). Opredelenie ostatochnyih antibiotikov $\mathrm{v}$ produktah zhivotnogo proishozhdeniya [Determination of residual antibiotics in animal products]. ENU im. L.N. Gumileva - ENU. LN Gumilyov, 6, 93-95 (in Russian).

Prescott, J. F., Sivendra, R., \& Barnum, D. A. (1978). The use of bacitracin in the prevention and treatment of experimentally-induced necrotic enteritis in the chicken. Can Vet J., 19(7), 181-183. https://www.ncbi.nlm.nih.gov/pmc/articles/PMC1789 416.

Shershnev, E. S., Mamykonyan, M. L., \& Laryonov, V. H. (1998). Osobennosty podkhoda SShA k voprosam kontrolya kachestva prodovol'stvyya [Features of the US approach to food quality control issues]. Pyshchevaya promushlenost - Food processing industry, 7, 52-55 (in Russian).

Smith, J. L., \& Weinberg, E. D. (1962). Mechanisms of antibacterial action of bacitracin. J Gen Microbiol., 28(3), 559-569. doi: 10.1099/00221287-28-3-559.

Sosina, Yu. A., Kartseva, E. A., Karamyisheva, E. I., \& Lyashenko, E. A. (2012). Vyiyavlenie ostatochnyih kolichestv antibiotikov v myase uboynyih zhivotnyih $\mathrm{i}$ ptitsyi [Identification of residues of antibiotics in the meat of slaughtered animals and poultry]. Aktualnyie problemyi infektsionnoy patologii i biotehnologii Actual problems of infectious pathology and biotechnology, 6, 178-180 (in Russian).

Stutz, M. W, Johnson, S. L., \& Judith, F. R. (1983). Effects of diet, bacitracin, and body weight restrictions on the intestine of broiler chicks. Poult Sci., 62(8), 1626-1632. doi: 10.3382/ps.0621626. 